Currículo sem Fronteiras, v. 19, n. 3, p. 1424-1437, set./dez. 2019

\title{
LAS ESCUELAS VAN AL CINE NA ARGENTINA E NO BRASIL? A institucionalização do cinema na escola pública argentina e reflexões para a escola brasileira
}

\author{
Bruna Donato Reche \\ Instituto Federal Catarinense \\ Maria Cristina da Rosa Fonseca da Silva \\ Universidade do Estado de Santa Catarina
}

\begin{abstract}
Resumo
Objetiva-se, neste artigo, refletir sobre a contribuição do cinema como linguagem artística na construção de práticas pedagógicas no espaço escolar brasileiro. Para tanto, apresenta uma revisão bibliográfica exploratória e descritiva sobre o projeto Las escuelas van al cine desenvolvido pelo Instituto Nacional de Cine y Artes Visuales (INCAA) argentino desde 2016, em parceria com a França. Recorreu-se ao estudo comparado ao se observar a crescente regulamentação educacional por organizações supranacionais em países como Brasil - sobretudo a partir da lei 13.006 de 2014 - e Argentina. Os dados apresentados foram retirados dos sítios oficiais do INCAA e de artigos oriundos da plataforma Scientific Electronic Library On-line (SCIELO). O cinema na escola potencializa os modos de aprender e o pensamento crítico, entre outros aspectos formativos descritos neste texto.
\end{abstract}

Palavras-chave: Cinema. Escola. Linguagem artística. Arte Contemporânea.

\begin{abstract}
The objective of this article is to reflect about the contribution of Cinema as an artistic language in the construction of pedagogical practices on the Brazilian school. For this purpose, it presents an exploratory and descriptive bibliographical review about the project Las escuelas van al Cine developed by the Instituto Nacional de Cine y Artes Visuales (INCAA) in Argentina since 2016 in association with France. Appealed to the comparative study when observing the growing educational regulation by supranational organizations on countries such as Brazil, above all since the law 13.006 of 2014, and Argentina. The data presented were taken from official website of the INCAA and the articles from the Scientific Electronic Library Online (SCIELO) platform. Cinema at school strengthens the ways of learning and the critical thinking, among others formatives aspects described in this text.
\end{abstract}

Keywords: Cinema. School. Artistic Language. Contemporary Art. 


\section{Introdução}

Vivemos a ressignificação dos espaços sociais e das relações políticas, que implicam o repensar da cultura e do fazer cultural, da arte e do fazer artístico. Na contemporaneidade, como aponta Eagleton (2011), a cultura tornou-se uma preocupação vital, é destaque na vida social, sobretudo por meio das mudanças estruturais do Capitalismo e das interações promovidas no contato com as constantes imigrações étnicas ao redor do globo que resultaram em uma cultura de massa comercialmente organizada.

A ruptura das concepções que compunham as organizações sociais surge, principalmente, com a acessibilidade às mídias tecnológicas e audiovisuais de comunicação, o fortalecimento do pluralismo de culturas, de concepções diversas, o lugar de fala, o espaço de escuta e, assim, as instituições se reconfiguram diante das crises e colapsos que suas próprias regras, anteriormente rígidas e representativas de um modo muito determinado de vida social, culminaram. A escola é uma dessas grandes instituições que tem a força de conduzir toda uma nação e que também vive a ruptura de paradigmas tradicionais de pensamento educacional diante da confluência de ideias dos sujeitos que a compõe. Para Chervel (1990, p. 11), seu papel é duplo: “[...] de fato ela forma não somente os indivíduos, mas também uma cultura que vem, por sua vez, penetrar, moldar, modificar a cultura da sociedade global".

Ao pensar a educação escolar em tempos em que os recursos tecnológicos e midiáticos estão se tornando, cada vez mais - sobretudo para as novas gerações -, mediadores da vida social, torna-se fundamental introduzir e relacionar esses recursos em práticas educativas que exprimam a função social da escola objetivada na produção dos conhecimentos elaborados pela humanidade e na formação baseada na autonomia, na criticidade e nos diretos humanos para uma sociedade emancipatória (SAVIANI, 2007).

Machado (2007, p.10) menciona que: “[...]. Se toda arte é feita com os meios de seu tempo, as artes midiáticas representam a expressão mais avançada da criação artística atual e aquela que melhor exprime sensibilidades e saberes do homem no início do terceiro milênio”. Ao considerar que, entre suas atribuições, a escola tem como função proporcionar a fruição, a reflexão e a criatividade com base nas linguagens artísticas e seus signos, sob o fundamento da liberdade em divulgar a cultura, a arte e o saber (BRASIL, 1996), define-se, então, um elemento pedagógico que subsidia a descoberta, o encanto, o estudo e a produção da arte na escola formal, sobretudo se se articular o cinema enquanto linguagem artística propulsora dessas aprendizagens.

Este artigo é parte de uma tese de Doutorado em Educação em andamento que relaciona Cinema, Educomunicação e Formação de Professores. Com o objetivo de refletir sobre a contribuição do cinema como linguagem artística na constituição de práticas pedagógicas no espaço escolar brasileiro, especialmente a partir da lei 13.006 de 2014 que tornou obrigatória a exibição de duas horas mensais de filmes nacionais nas escolas de educação básica (BRASIL, 1996), apresenta-se aqui uma revisão bibliográfica exploratória e descritiva sobre o programa Las escuelas van al cine que convida o cinema nacional a adentrar a escola 
pública argentina, desenvolvido pelo INCAA, desde 2016, em parceria com o governo francês. Os dados apresentados foram retirados dos sítios oficiais do INCAA e de artigos submetidos à plataforma SCIELO. Assim, este artigo apresenta proposições iniciais de discussão sobre o cinema na escola básica ao tratar do caso argentino.

Países da América do Norte e Europa Ocidental há muito inseriram o cinema nacional como componente curricular e formativo em suas escolas públicas. A justificativa de escolha da experiência argentina decorre do fato de ser uma experiência recente, por se tratar de um país com tradição no fomento do audiovisual nacional e, sobretudo, pela intenção de fortalecer e disseminar ações político-culturais latino-americanas.

Para isso, recorre-se a um estudo comparado, ainda que exploratório e descritivo, uma vez que as mudanças inerentes ao processo de Globalização desencadearam crescente regulamentação educacional de organizações supranacionais e seus documentos normativos que visam a prescrever emendas e elaborar políticas educativas aos diversos países, tais como Brasil e Argentina. Há diversas críticas em relação à essa regulamentação, assim, o estudo comparado contribui com "[...] subsídios para sistematizar e encaminhar políticas que contemplem as particularidades e especificidades das diferentes culturas que compõem a sociedade, de forma a thes oferecer alternativas" (CARVALHO, 2014).

A Argentina é um dos países com melhor qualidade de vida na América do Sul, um sistema educacional obrigatório e gratuito às crianças entre os seis e 14 anos e um nível de analfabetismo abaixo, de quatro por cento (ANDRADE, 2009). No caso do Brasil, apesar de também possuir um sistema educacional obrigatório e gratuito, destinado às crianças entre quatro e 16 anos, a qualidade da educação pública brasileira passa, há tempos, por uma crise estrutural, tendo um nível de sete porcento da população brasileira em condição de analfabetismo, o que corresponde a aproximadamente 14 milhões de pessoas (VILLAS BOAS, 2018), ainda que a promessa em erradicar o analfabetismo no país esteja datada desde a Constituição Federal de 1988.

Aqui, delimita-se o cinema como uma das expressões artísticas de importância singular nas ações educativas e pedagógicas escolares e, então, concorda-se com Fresquet (2013, p. 44) ao afirmar que: "Por um lado, a escola se apresenta como o lugar do tradicional do ensino, da regra e da transmissão padronizada da cultura [...]. Por outro, [...] aparece como lugar privilegiado de acesso coletivo ao cinema que foge, minimamente, do consumo hegemônico".

A presença do cinema na escola potencializa os métodos de se aprender e se instigar o pensamento crítico, abre brechas para que a linguagem artística converse com a cultura acadêmica, possibilita que os jovens expressem seus sentimentos, desejos e sonhos de outros jeitos e contribui para que se tornem cidadãos e ativos na sociedade. Assim, há relação direta com contemporaneidade e suas expressões artísticas que permitem aos sujeitos tornarem-se atores-receptores de suas trajetórias. 


\section{A arte contemporânea e o cinema: possibilidades de produção cultural e de cultura escolar}

O fascínio pelo cinema surgiu naquela cena da vida cotidiana em uma estação de trem, projetada como espetáculo pelos Lumières. Morin (1970, p. 83) acredita que a intenção dos irmãos foi que as pessoas se maravilhassem com aquilo que não lhes despertava mais espanto, como suas casas, seus conhecidos e suas próprias vidas. Nesse sentido, o cinema “[...] apodera-se das coisas quotidianamente desprezadas, manejadas como utensílios, gastas pelo hábito, e desperta-as para uma nova vida: se as coisas eram reais, tornam-se agora presentes”.

Por outro lado, pode-se compreender o cinema como uma prática social dentro de um sistema de mercadorias que, tendo o filme como produto, influencia a produção de outros artefatos, como documentários, curtas-metragens e, até mesmo, vídeos amadores disponibilizados em plataformas populares como o YouTube. Conforme relata Fresquet (2013, p. 23), “[...]. Hoje, muitas crianças filmam - sem nunca terem sido ensinadas -, com seus celulares e pequenas câmeras de fotografia” e compartilham esses vídeos com os demais por meio dos aparelhos tecnológicos e conectados à Internet, fomentando, assim, mídias de comunicação e expressão alternativas.

A arte está em todo lugar, nos museus e espaços públicos, nas premiações e nos memes das redes sociais, logo, quem pode denominar o que é arte na contemporaneidade? E, nesse sentido, atualmente, quem pode ser considerado um artista? São dúvidas que alguns estudos sobre os quais a antropologia, a sociologia, a filosofia e a arte têm se debruçado, sobretudo a partir das rupturas na expressão de se fazer, receber e interagir com a arte, na concepção do papel de ator-receptor das obras artísticas que a arte na contemporaneidade apresenta, permitindo participação mais democrática nos trâmites de produção e consumo artísticos.

Em uma perspectiva ocidental, os movimentos artísticos oriundos desde a modernidade vêm rompendo com as regras e princípios que fundamentaram o conceito de Arte até o início do século XIX. A Arte Moderna almejou desvincular-se do passado tradicional e, assim, seus movimentos artísticos resultaram em um novo significado para a obra de arte, inaugurando a ênfase na reflexão sobre os meios, processos e métodos de representação artística.

Tendo como base as modificações econômicas, políticas e sociais iminentes da sociedade capitalista em ascensão, sobretudo com a urbanização e industrialização, as vanguardas modernistas representavam o desejo dos artistas em retirar a obra de arte do habitual pedestal contemplativo, contestá-la e desloca-la do invólucro das regras.

Às transformações relativas às concepções de arte, atrelou-se também a discussão sobre novos conceitos de cultura fundamentais, como aponta Eagleton (2011 p. 179), ao futuro das sociedades ocidentais desorientadas quando do declínio “[...] da identidade imperial, americanização cultural, a influência crescente do consumismo e dos meios de comunicação de massa, e as vozes cada vez mais articuladas de intelectuais oriundos da classe operária”. Essa expressão também foi sentida na produção audiovisual de meados do século XIX, e o Cinema Novo é um dos movimentos que se fortaleceram nessa perspectiva.

Parte das elites intelectuais pôde encontrar no Cinema Novo, sobretudo brasileiro, uma força cultural que expressasse suas inquietações políticas, estéticas e antropológicas em um 
diálogo cultural com outros países. Os filmes do Cinema Novo não têm como objetivo o puro divertimento, mas sim levar ao público informação a respeito das questões sociais recorrentes na grande população. Desse modo, “[...]. A elite, por ser dependente dos centros culturais dos países industrializados, hesitava em aceitar o Cinema Novo. A repercussão internacional dos filmes deu-lhe certa segurança. Se a Europa elogiava, é que algo de elogiável devia haver” (BERNADET, 1980, p. 54).

Por outro lado, pode-se compreender o cinema como uma prática social e cultural com dimensões de produção, consumo, fruição e significação. Logo, o cinema contemporâneo conta com produções cada vez mais acessíveis, meios de distribuições alternativos, especialmente pelas dezenas de plataformas de vídeo on-line que potencializaram a divulgação de filmes independentes e alternativos, sem que se perca o espaço do filme massmedia e comercial.

As inovações tecnológicas contribuem exponencialmente para novas maneiras de se produzir e consumir cinema como, por exemplo, a superalta definição de imagem, cujo alcance de projeção conta com mais oito milhões de pixels por quadro de resolução em grandes telas, acessível à população em breve, o que tornará visíveis imagens em escalas micro e macro de lugares e coisas nunca vistas a olho nu: "[...] cientistas e inventores procuram cada vez mais 'as imagens jamais vistas', agora para trazer o universo ao mundo não apenas para tornar visíveis imagens anteriormente invisíveis, mas também para transmitilas” (CHAIA, 2015, p. 278 - grifos do autor), o que têm tornado comum experiências de imersão digital, telas e filmes interativos em que o espectador controla as ações da metragem com base em suas escolhas, tal como o filme Bandersnatch da plataforma Netflix, transgredindo a velha relação emissor-receptor, bem como a propulsão que a Digital Art tem tomado ao longo desses últimos anos como expressão artística da contemporaneidade.

A Arte Contemporânea toma para si a diversidade característica da Arte Moderna e rompe de vez com as regras, técnicas e concepções sobre o que é ou não arte, inclusive com o apelo visual característico dos 'ismos' da Arte Moderna. Embebida nas hibridações eminentes dos contextos sociais e econômicos vigentes, principalmente após as duas grandes guerras que trazem como consequência a quebra de modelos, paradigmas e ideologias, a Arte Contemporânea é também plural, diversa, heterogênea e flexível (ORTIZ, 2000 apud BOSCO, 2011).

Na contemporaneidade, o cinema tornou-se meio de ampliação, ou mesmo massificação, de aspectos culturais antes restritos a um número pequeno de pessoas. Assim, para muitos estudiosos, o cinema é ótica de compreensão da sociedade, tornando-se disciplinas universitárias ou em cursos antropológicos, sociológicos, históricos e críticos de artes que não pretendam uma formação técnico-prática, mas cultural mais ampla (BERNADET, 1980).

A arte é uma linguagem e também uma maneira de expressividade exclusiva da humanidade que medeia as relações dos sujeitos consigo mesmos e com os demais, que auxilia na leitura do mundo ao redor e contribui para a leitura da palavra gramatical e alfabética, por isso é componente curricular obrigatório da educação básica brasileira.

O cinema na escola pode contribuir efetivamente para a constituição do saber plural com base nas imagens e pelo contato com os demais, bem como promover a autonomia dos alunos 
e a cidadania exercida por eles, para além do academicismo, ao se permitir a exploração dos diversos espaços formativos que podem estar presentes na escola. A fruição das cenas e de seus sons, o contato com os diversos estilos artísticos estimula a linguagem artística como manifestação da diversidade, da criticidade e, sobretudo, da expressividade do ser em se relacionar com o mundo e com os outros.

\section{Las escuelas van al cine na Argentina e algumas reflexões sobre essa experiência}

Com alteração da Lei de Diretrizes e Bases da Educação Nacional (LBD) pela de $n^{0}$ 13.006 de 2014, que torna obrigatória às escolas de educação básica a exibição de duas horas de filmes brasileiros, novas demandas são postas ao trabalho escolar. Fresquet e Migliorin (2015) explicam que o trâmite da legislação teve como pano de fundo a justificativa de uma necessidade em se apoiar a indústria cinematográfica nacional: “[...] a única forma de dar liberdade à indústria cinematográfica é criar uma massa de cinéfilos que invadam nossos cinemas, dando uma economia de escala” (BUARQUE apud FRESQUET; MIGLIORIN, 2015, p.5).

Decorrente dessa afirmativa, ausente na redação legal, questiona-se a incumbência da escola em criar uma massa de cinéfilos, sobretudo se a compreendermos a partir de perfil de consumidora que passa para uma sociedade mercadológica, contradizendo a real função escolar que é a construção do conhecimento elaborado pela humanidade histórica e coletivamente (SAVIANI, 2003). Como se verá, ainda que o projeto argentino de relacionar cinema e escola tenha como objetivo maior desenvolver espectadores do cinema nacional, há uma proposta formativa que a ampara pedagogicamente. Para além, há de se atentar para que não seja mais um modo de dizer à escola e aos professores suas funções.

Teixeira, Azevedo e Grammont (2015) contribuem com a discussão ao refletir que, para ser aplicável, na melhor das intenções pedagógicas e formativas, há de se esperar que agentes dos circuitos cinematográficos de realização, distribuição e exibição interajam com a proposta da escola e da comunidade escolar ao criar o espaço para o cinema, diferente daquele que reproduza, como afirmam Fresquet e Migliorin (2015, p. 10), as imagens que "[...] bombardeiam todas as casas com a televisão”. Quais imagens são coerentes ao espaço da escola, então?

Essa questão se aproxima mais de um caminho do que de uma verdade. Ao lembrar as palavras de Bergala (2008, p. 33), "Se o encontro com o cinema como arte não ocorrer na escola, há muitas crianças para as quais ele corre o risco de não ocorrer em lugar nenhum”. Desse modo, que o filme estimule experiências singulares de ritmo, diversidade estética e alteridade (BERGALA, 2008) nos alunos e que, para tanto, haja regulamentações e reais espaços para que o cinema como arte entre na escola.

Ao pensar nas possibilidades de apropriação da linguagem cinematográfica que se abrem como meio de aprendizagem para as demais linguagens audiovisuais dentro da escola, acredita-se na presença do audiovisual como mediador, e mesmo fim, na produção de vídeos 
e metragens pelos próprios alunos, de uma prática pedagógica atrelada à educação estética e crítica, muito além da simples exibição. Estética no sentido de ser uma suspensão provisória da causalidade do mundo, das relações conceituais que nossa linguagem forja e que se dá pela percepção global do meio em que se vive e se estabelecem relações (DUARTE, 1994).

Crítica no sentido da capacidade para se distinguir a fantasia da realidade, compreensão de que as mensagens da mídia são constructos com fins específicos, compreensão do papel econômico, político, social e cultural da mídia nas comunidades locais e globais, compreensão dos direitos democráticos, negociação e resistência, identidade cultural e cidadania do seu grupo, bem como dos outros (FEILITZEN, 1999 p. 29).

Ao complementar sobre a importância do sentido crítico em relação ao cinema, Bernadet (1980) ilustra que um filme comercial apresenta determinados atributos motivadores para que potenciais espectadores saiam de suas casas com destino ao cinema, que o escolham em detrimento de outros disponíveis nas demais salas de exibição e, que, portanto, contribuam aos lucros das exclusivas indústrias cinematográficas dominantes no mercado global: "Para conquistar a maior quantidade possível de espectadores, para ser um filme de massa, para proporcionar grandes lucros, um filme não pode se dar ao luxo de desprezar nenhum espectador potencial” (BERNADET, 1980, p. 31).

Morgadouro (2011) assinala que o uso do cinema e do rádio nas escolas, até meados do século 20, restringia-se à função interativa com os aparelhos tecnológicos. Com o barateamento de produção e massificação da compra e consumo dos programas televisivos, novas possibilidades de se pensar a relação educação e audiovisual, no que tange aos recursos didáticos e expressões artísticas, também ganharam força à época.

A compreensão do cinema como objeto de intervenção educativa há muito tempo está consolidada em diversos países, mas no Brasil ainda está em vias de sê-lo. É difícil romper com a ideia de cinema apenas como um recurso instrumental quando a escola e seus professores não dispõem de espaços que discutam o cinema em sua perspectiva ética e estética.

No que diz respeito à educação midiática, os anos de 1970 se tornaram marcos históricos às iniciativas em países como Inglaterra, Austrália e Canadá que, com apoio governamental, introduziram o cinema como componente curricular escolar. E no início dos anos 2000, o governo francês aprovou o programa Éducation aux Médias que expandiu e fortaleceu a linguagem do cinema nos currículos das escolas francesas (SOARES, 2014).

Na América Latina, as iniciativas educacionais relativas às mídias permearam grupos sociais organizados, especialmente os movimentos populares e a comunicação popular subsidiada na pedagogia de Paulo Freire que: "imprimiram com clareza a orientação social, política e cultural e a elaboraram como uma pedagogia do oprimido como uma educação para a democracia e um instrumento para a transformação da sociedade” (KAPLÚN, 2002, p. 45).

Quanto às propostas brasileiras, destaca-se a Rede Kino que surgiu, em 2009, da iniciativa em unir pessoas e instituições de ensino que promovessem experiências relacionadas ao cinema e educação. O intuito da rede é ampliar o debate sobre a temática e estabelecer relações e parceiras com educadores, pesquisadores, cineastas, produtores e gestores da educação (REDE KINO, 2009). 
Dentre seus projetos, há o Programa de Alfabetização Audiovisual de Porto Alegre, em parceria com as Secretarias Municipais de Cultura e de Educação da cidade, o Ministério da Educação e da Faculdade de Educação da Universidade Federal do Rio Grande do Sul, que promove oficinas de introdução à realização audiovisual nas escolas da Rede Municipal de Educação de Porto Alegre, formações e cursos de extensão universitária a professores da Rede Pública de Ensino, comanda o Festival Escolar de Cinema que visa a promover o acesso e ampliar o repertório audiovisual dos estudantes da Rede Municipal de Ensino (BARBOSA, 2015).

No caso argentino, no ano de 2016, o INCAA, em parceria com a França, estimulou o cinema como componente curricular das escolas de educação básica em âmbito nacional, com o objetivo de, com base em estruturas física, material e pedagógica, fortalecer audiências para o cinema argentino no trabalho escolar por meio da linguagem cinematográfica.

Essa medida trata de um conjunto de ações do INCAA para fortalecimento das audiências do cinema argentino. Em 2004 implementou-se a resolução no 2016/INCAA que trata sobre a cota de filmes nacionais em cinemas e salas de exibição cinematográfica no país: "[...]. Essas políticas estabeleceram um mínimo de estreias mensais de filmes argentinos e fixaram normas acerca da quantidade mínima de espectadores por exibição" (MOGUILLANSKY, 2016, p. 168 - tradução nossa).

Um estudo denominado Encuesta Nacional de Consumos y Prácticas Culturales Adolescentes, realizado pelo Sistema de Informação Cultural da Argentina (SINCA) em 2016, apontou que sete a cada dez adolescentes argentinos foram ao cinema no último ano, entretanto, apenas três entre os dez afirmaram ter assistido a um filme nacional (BRAGINSKI, 2016). Assim, "A ideia é impulsionar diferentes iniciativas para que os mais jovens descubram, entre outras coisas, que o cinema nacional também tem histórias voltadas para eles e o fascínio que significa descobri-las na telona”. (LAS ESCUELAS VAN... 2019 - tradução nossa).

Em dados referentes ao mesmo estudo realizado pelo SINCA em 2014 e com base no estudo de Borello y Quintar (2014 apud MOGUILLANSKY, 2016), 60\% dos entrevistados não tinha o costume de ir ao cinema em virtude dos seguintes fatores: classe social a que pertenciam, geralmente mais pobres; pelo pouco acesso ao consumo de bens culturais, sobretudo porque cidades argentinas com menos de 100 mil habitantes comumente não possuem salas de exibição cinematográficas; e pelos costumes familiares não praticarem o hábito de ir ao cinema. Uma forma de potencializar o contato com o cinema nessas cidades e torná-lo acessível a toda a população foi a fundação estatal de salas de exibição de filmes do circuito Espacios INCAA. Essas iniciativas fazem jus ao chamado cinema de arte por Bernadet (1980, p. 48) ao afirmar que o sentido da evolução do cinema são as iniciativas sociais de promoção à cultura para a população em geral.

Historicamente, o ato de ir ao cinema faz parte da classe média argentina, sobretudo a partir das crises político-econômicas dos anos de 1990 e o desconchavo de setores pobres e ricos, "[...] sendo este último o público privilegiado dos cinemas a partir de então. O cinema move-se gradualmente em direção ao espaço íntimo e privado do lar, modificando assim seu sentido social” (WORTMAN, 2008 apud MOGUILLANSKY, 2016, p. 172 - tradução 
nossa). Moguillansky (2016) explica que a elitização do consumo de filmes por meio do cinema culminou em estratégias dos grandes empresários em reduzir a diversidade de temas a uma determinada classe social, comprometendo o acesso cultural mais ampliado.

Essa ideia é muito semelhante a apresentada por Bernadet (1980) ao explicar o sistema de cópias de uma película que se dissemina ao redor do planeta quase imediatamente a sua finalização, sobretudo com mecanismos digitais desenvolvidos no início deste século, levando consigo um poder ideológico de longo alcance: “[...] a burguesia triunfante absorve as matérias-primas dos países dominados, faz circular suas mercadorias pelo mundo, conquista novos mercados, é colonialista. O cinema vai logo encontrar os canais por onde circular” (BERNADET, 1980, p. 12).

Com a força da indústria e propaganda cinematográfica dos filmes comerciais, sobretudo os hollywoodianos, as salas de exibição de bairro e os pequenos cinemas tendem a desaparecer, dando espaço para que as confortáveis e bem equipadas salas de cinema das grandes franquias concentrem-se em pontos, cujo poder econômico é mais elevado, o que culmina no consumo de bens culturais apenas pelas camadas mais ricas da população (BERNADET, 1980).

Nesse sentido, o projeto que envolve cinema nas escolas argentinas foi assinado em fevereiro de 2016, na ocasião da visita do então presidente François Hollande à Argentina sob a parceria com o Institut Français, que há mais de trinta anos desenvolve um projeto semelhante nas escolas francesas. Um dos compromissos deste projeto é exibição de filmes argentinos no projeto francês e filmes franceses no projeto argentino como meio de difusão do cinema que não o americano.

A pretensão do projeto argentino é possibilitar que mais de 30 mil estudantes conheçam e experienciem as telas de cinema do Instituto para assistirem a filmes nacionais (LAS ESCULAS VAN... 2019). Sobre iniciativas assim, Fresquet (2013, p. 98) escreve que "[...]. A possibilidade de ver filmes que pouco provavelmente assistiriam com sua turma de pares é, também, quase um segredo" entre os alunos que compartilham da experiência e a reconstroem na memória, moldando também novos sentidos sobre o espaço ao redor.

As escolas que participaram do primeiro ano do projeto foram selecionadas pelos Ministérios da Educação das províncias argentinas sob as condições de ser escola pública localizada em comunidades onde o acesso a filmes e ao cinema seja restrito e à existência de um prédio do INCAA na região. Os filmes escolhidos tiveram como critérios: serem destinados a adolescentes e que possibilitassem o debate, quando em sala de aula, sobre as questões sociais nacionais (BRAGINSKI, 2016).

Com a expansão do projeto, a participação das escolas tornou-se voluntária, entretanto, ao aderi-lo, elas se comprometem a levar os alunos durante o horário escolar às sessões exclusivas ao menos duas vezes ao ano, fomentar a discussão dos filmes assistidos em sala de aula, bem como a participarem das capacitações ofertadas pela Escuela Nacional de Experimentación y Realización Cinematográfica (ENERC). As escolas que desejam participar contam com materiais didáticos específicos que contribuem para análises dos filmes e debates em sala de aula (LAS ESCULAS VAN..., 2016). 
O programa pedagógico se define por objetivos específicos de acordo com a faixa etária dos alunos: de seis a nove anos, a proposta é de encantar os alunos com a tela grande, exibindo filmes, cujas histórias lhes sejam acessíveis à compreensão. Com os alunos de 16 aos 18 anos, visa-se a consolidar conhecimentos que desenvolvam espectadores entendidos de técnicas e estilos, bem como despertá-los para as questões sociais vigentes (LAS ESCUELAS VAN..., 2016).

Os filmes são selecionados por uma Comissão constituída por cinco membros designados pela presidência do INCAA: um profissional da educação, um representante de festivais argentinos, um roteirista, um diretor de cinema e um docente da ENERC. Além disso, são ofertadas cinco capacitações às escolas participantes, ministradas pela ENERC: 1destinada à análise dos filmes escolhidos, em sala de aula, após sua exibição; 2- relativa à utilização pedagógica dos filmes em sala; 3- voltada para a alfabetização da linguagem cinematográfica, bem como sobre a história do cinema; e 4- destinada à análise dos filmes escolhidos e assistidos, mas sob a perspectiva sociológica como reflexo de um feito social ou espelho do mundo (LAS ESCUELAS VAN..., 2016).

Ainda que o projeto tenha como objetivo político, até mesmo econômico, de aumentar a audiência para o cinema argentino, reflete-se que essa experiência do fruir e da conversa sobre as películas poderá tornar-se espaço de importante formação crítica e estética para a linguagem cinematográfica e apropriação das mídias e dos meios audiovisuais que contribuam para as escolhas pessoais dos alunos em seus percursos de vida.

Quando a educação - tão velha quanto a humanidade mesma, ressecada e cheia de fendas - se encontra com as artes e se deixa alagar por elas, especialmente pela poética do cinema - jovem de pouco mais de cem anos -, renova sua fertilidade, impregnando-se de imagens e sons. Atravessada desse modo, ela se torna um pouco mais misteriosa, restaura sensações, emoções, e algo da curiosidade de quem aprende e ensina (FRESQUET, 2013, p. 19/20).

Além disso, as ações realizadas pelo projeto podem fortalecer as trajetórias escolares e formativas dos alunos, em um sentido próximo ao que Rancière denomina o espectador emancipado (2012, p.17):

A emancipação, por sua vez, começa quando se questiona a oposição entre olhar e agir, quando se compreende que as evidências que assim estruturam as relações do dizer, do ver e do fazer pertencem à estrutura da dominação e da sujeição. [...]. Ele observa, seleciona, compara, interpreta. Relaciona o que vê com muitas outras coisas que viu em outras cenas, em outros tipos de lugares. Compõe seu próprio poema com os elementos do poema que tem diante de si.

Nesse sentido, programas voltados à inserção da arte, e nesse caso o cinema, são importantes no que diz respeito ao conhecimento para o fortalecimento de iniciativas que se unam à escola e ao seu trabalho pedagógico em prol de uma educação e alfabetização mediadas artisticamente. Entre as atividades acadêmicas, a escola precisa delimitar “[...] um 
tempo e um espaço para cuidar dos sonhos das crianças. Alimentá-los, transforma-los. Leválos a sério. Abrir, na escola, alguma porta para o irracional, para dar asas à imaginação sem tentar procurar saber o porquê das coisas” (FRESQUET, 2013, p. 91).

A educação para as mídias e para os processos comunicativos vigentes é uma necessidade atual. Assim, acredita-se que o cinema na escola estimula a criticidade e consciência frente ao imediatismo e consumismo desencadeados pelo uso compulsivo de mídias de comunicação e informação e possibilita a reflexão sobre as mensagens midiáticas tornando o aluno ativo, responsável e comunicador de suas percepções sobre si e seu redor. Como aponta Saviani (2007, p. 60): “Quanto mais adequado foi nosso conhecimento da realidade, tanto mais adequados serão os meios de que dispomos para agir sobre ela”.

Não significa aparelhar a escola de instrumentos tecnológicos e usá-las de maneira deliberada, mas questionar os modelos institucionais, as mentalidades e a cultura dos sistemas educacionais tradicionais que ainda hoje refutam a necessidade de repensar a educação frente às mudanças estruturais da sociedade e pensar, sobretudo, nos papéis do professor e aluno dentro da instituição. Isso porque, ensinar com base dos diversos campos de conhecimentos progressivamente em direção a uma cultura global da sociedade estabelece-se como um dos aspectos mais importantes da escola (CHERVEL, 1990).

A arte, sobretudo a contemporânea, permite e convida o sujeito comum a participar e interagir, tornando-se obra e criador ao mesmo tempo. O cinema contemporâneo, enquanto linguagem influenciada pelos diversos períodos artísticos, também representa essa perspectiva interativa, comunicadora e disseminadora de valores e hábitos sociais. Torná-lo meio de emancipação social, de educação de sujeitos autônomos e empoderados na sociedade é desejo maior no espaço escolar, a partir da lei 13.006 de 2014.

A arte possibilita a expressão maior do sujeito em seus desejos e virtudes, sentimentos e distorções. Transforma o homem pelos conceitos e valores característicos da humanidade e transforma-o em humano. A escola objetiva conduzir cada um dos seus com base nos conhecimentos constituídos pela experiência e pensamento humanos ao longo do tempo. Juntas, o potencial é gigante. Que a prática argentina contribua para o Brasil e países vizinhos, potencializando a força latino-americana a pensar ações formativas que consolidem e impulsionem as linguagens artísticas na escola na responsabilidade de possibilitar que os alunos se tornem sujeitos criadores de suas existências e de modos democráticos de convivência.

\section{Considerações finais}

A arte é componente curricular básico da educação brasileira, justamente por sua importância no processo de descoberta das linguagens, de humanização dos alunos e de transformação destes em sujeitos críticos e atuantes. Desde 2014, o cinema tem artigo próprio na LDB enfatizando a obrigatoriedade de sua presença na escola, entretanto, ao não descrever a concepção filosófico-social e os procedimentos metodológicos que a ampara, pode ser interpretada como mera exibição de duas horas mensais na sala de aula ou qualquer espaço 
escolar. Assim, há de se produzir estudos que fomentem e traduzam o potencial construtivo e pedagógico do cinema como meio, linguagem e produto das aprendizagens escolares.

Este estudo sobre a experiência do projeto educacional Las escuelas van al cine, desenvolvido pelo INCAA que trata do cinema nacional na escola pública argentina., ainda que preliminar, não teve a intenção de hierarquizar práticas formativas sob critérios qualitativos, mas sim a de disseminar estudos que forneçam subsídios reflexivos sobre a elaboração de um projeto nacional brasileiro que relacione cinema e educação por sua potencialidade pedagógica e construtiva de conhecimentos, autonomia, empoderamento e criticidade aos alunos e a toda comunidade escolar.

A presença do cinema na escola enriquece os métodos de aprendizagens, estimula o pensamento crítico, abre brechas para que a linguagem artística converse com a cultura acadêmica, possibilita que os jovens expressem seus sentimentos, desejos e sonhos e os incentiva a tornarem-se atores de suas vidas. Sua experiência é vasta em países europeus e norte-americanos e tem a possibilidade de se concretizar pedagogicamente também no Brasil. Assim, descreveu o caso argentino, ainda que seu como objetivo político ou mesmo econômico vise a aumentar a audiência para o cinema nacional argentino, pois se acredita que sua experiência contribuirá para a autonomia dos alunos frente às questões sociais emergentes, tal como um espectador emancipado em suas próprias trajetórias de vida escolar e social.

Nesse sentido, o projeto descrito favorece uma proposta formativa brasileira ao revelar aspectos sobre a institucionalização pedagógica do cinema na escola em um âmbito nacional; sobre o respaldo técnico, físico e material do trabalho em sala de aula; sobre a troca de conversa com pessoas ligadas ao trabalho de produção cinematográfica e alunos das redes, em um descobrir a produção audiovisual como linguagem expressiva de questões sociais que podem assemelhar-se as que eles mesmos passam, e assim os fortaleça a agirem sobre suas próprias realidades; sobre um estimular de sonhos e pensamentos que permitam os alunos colocá-los em prática no espaço ainda muito tradicional da escola, sendo eles mesmos protagonistas de suas aprendizagens e sendo descobridores de possibilidades que flexibilizem e articulem o trabalho escolar com a comunidade.

As inovações tecnológicas adentram a escola e suas salas de aula a passos lentos, mas, a cada dia, estudos demonstram sua importância como mediadores e até mesmo como produtos de uma educação escolar engajada com a condução de seus alunos para a sociedade contemporânea. Logo, o que é o cinema, se não também uma mídia tecnológica que une os demais e ainda provoca a formação para linguagens distintas, mas complementares, da linguagem gramatical e alfabética escolar?

As experiências com telas de imersão digital, aparelhos e filmes interativos permitem imaginações tais que contradizem com o modelo tradicional de pensamento e método escolar. Os alunos querem e têm o direito a práticas educativas coerentes com a realidade em que vivem e que lhes permitam apropriar-se dos códigos, conceitos, valores e aspectos dessa sociedade em câmbio constante de paradigmas e ideologias que confrontam e perpassam seus sujeitos plurais e suas necessidades, obrigando-os, assim, a serem críticos e atuantes democraticamente. 
A arte contemporânea representa a possibilidade de tudo e todos serem processos e objetos artísticos, coloca o sujeito ordinário e situações cotidianas como foco da mais surpreendente experiência estética, mas para isso requer, de algum modo, um processo criativo que perpasse aspectos sociais, culturais, políticos ou econômicos que toquem o íntimo daquele que interage com ela ou a observa.

Assim, ser artista, na contemporaneidade, requer uma profunda compreensão histórica e cultural de um contexto ou grupo. No mesmo sentido, a escola se propõe a formar sujeitos mediados pelo conhecimento histórico e cultural produzido pela humanidade ao longo dos anos. Logo, arte e escola se imbricam no objetivo comum de emancipá-los de lhes dar voz e fundamentação para que sejam ouvidos. Espera-se que a escola não forme apenas pessoas, mas artistas de suas próprias existências e atores de uma sociedade mais humana e equitativa. O cinema é uma destas linguagens que possibilitará esse caminho, se bem pensando e empregado no espaço comum de uma sala escolar escura.

\section{Referências}

ANDRADE, Dalila Oliveira. Políticas educacionais e regulação no contexto latino-americano: Argentina, Brasil e Chile. Revista Linhas Críticas, vol. 15, núm. 28, enero-junio, 2009, pp. 45-62

BARBOSA, Maria Carmen. Programa de alfabetização audiovisual, 2015. Disponível em: http://alfabetizacaoaudiovisual.blogspot.com.br/?view=timeslide. Acesso em: 10 mai. 2017.

BERGALA, Alain. A hipótese-cinema. Rio de janeiro: Booklink/ UFRJ, 2008

BERNADET, Jean Claude. O que é Cinema? São Paulo: Brasiliense, 1980.

BOSCO, Maria Cristina. O ensino de arte contemporânea. Dissertação (Mestrado - Programa de Pósgraduação Interunidades em Estética e História da Arte. Universidade de São Paulo, 2011. 118 fls.

BRAGINSKI, Ricardo. Lanzanun programa para llevar a $\mathbf{3 0 . 0 0 0}$ chicos a ver cine nacional, 2016. Disponível em: https://www.clarin.com/sociedad/lanzan-programa-llevar-chicosnacional_0_BydHpWUF.html. Acesso em: 20 jan. 2019.

BRASIL. Lei de Diretrizes e Bases da Educação Nacional, 1996.

CARVALHO, Elma Júlia. Estudos comparados em educação: novos enfoques teórico metodológicos, 2014. Disponível em: http://periodicos.uem.br/ojs/index.php/ActaSciEduc/article/view/19012/12442. Acesso em: 10 abr 2017.

CHAIA, Miguel. Cinema \& Políticas. Rio de Janeiro: Azougue Editoral, 2015.

CHERVEL, A. História das disciplinas escolares: reflexões sobre um campo de pesquisa. In: Teoria \& Educação: Porto Alegre, n. 2, 1990, p. 177-229.

DUARTE JÚNIOR, João Francisco. Fundamentos estéticos da educação. Campinas: Papirus, 1994.

EAGLETON, Terry. A ideia de Cultura. São Paulo: Editora UNESP, 2011.

FEILITZEN, Cecilia Von. Educação para a Mídia, Participação Infantil e Democracia. In: (Org). A CRIANÇA E A MíDIA: Imagem, Educação, Participação, Unesco: Brasil, 1999.

FRESQUET, Adriana. Cinema e Educação: reflexões e experiências com professores e estudantes de educação básica, dentro e fora da escola. Belo Horizonte: Autêntica, 2013. 
; MIGLIORIN, Cezar. Da obrigatoriedade do cinema na escola, notas para uma reflexão sobre a Lei 13.006/14. In: Cinema e educação: a lei 13.006 Reflexões, perspectivas e propostas. Brasil: Unesco, 2015.

KAPLÚN, Mário. Una pedagogia de La comunicación: el comunicador popular. La Habana: Caminos, 2002.

LAS ESCUELAS VAN AL CINE. Plataforma del Programa, 2016. Disponível em: http://www.incaa.gob.ar/fomento-a-la-industria/promocion/las-escuelas-van-al-cine. Acesso em: 4 abr. 2017.

LAS ESCUELAS VAN AL CINE. Programas Institucionais, 2019. Disponível em: http://www.incaa.gov.ar/programas-especiales/las-escuelas-van-al-cine. Acesso em: 20 fev. 2019.

MACHADO, Arlindo. Arte e Mídia. Campinas: Papiros, 2007.

MORGADOURO, Cláudia de Almeida. Educomunicação e escola: o cinema como mediação possível (desafios, práticas e propostas). Tese de Doutorado em Educação, 428 fls. 2011.

MORIN, Edgar. O cinema ou o homem imaginário. Lisboa: Moraes editora, 1970.

MOGUILLANSKY, Marina. El nuevo cine de espectáculo como estrategia comercial: Un análisis de las tendencias del consumo de cine en salas. In: Revista Intercom: São Paulo, v. 39, n. 3. set./dez. 2016, p.167183.

RANCIÈRE, Jacques. O espectador emancipado. São Paulo: WMF Martins Fontes, 2012.

REDE KINO. Introdução, 2009. Disponível em: http://www.redekino.com.br/. Acesso em: 4 de abr. de 2017.

SOARES, Ismar de Oliveira. Educomunicação e Educação Midiática: vertentes históricas de aproximação entre Comunicação e Educação. In: Comunicação \& Educação: São Paulo. n. 2, jul/dez 2014 p. 15-26.

SAVIANI, Dermeval. Educação: do senso comum à consciência filosófica. Campinas: Autores Associados, 2007.

Pedagogia histórico-crítica: primeiras aproximações. Campinas: Autores Associados, 2003.

TEIXEIRA, Inês Assunção de C.; AZEVEDO, Ana Lúcia; GRAMMONT, Maria Jaqueline. O cinema pela escola: aproximações à Lei 13.006/2014. In: Cinema e educação: a lei 13.006 Reflexões, perspectivas e propostas. Brasil: Unesco, 2015

VILLAS BÔAS, Bruno. Analfabetismo cai no Brasil, mas 11,5 milhões não sabem ler, diz IBGE. Disponível em: https://www.valor.com.br/brasil/5533911/analfabetismo-cai-no-brasil-mas-115-milhoesnao-sabem-ler-diz-ibge. Acesso em: 15 fev. 2019.

\section{Correspondência}

Bruna Donato Reche: É Pedagoga e mestra em Educação pela Universidade Estadual de Londrina, é bacharelanda em Artes Visuais pelo Centro Universitário Internacional e doutoranda em Educação pela Universidade do Estado de Santa Catarina. É docente efetiva da Instituto Federal Catarinense.

E-mail: bruna.reche@ifc.edu.br

Maria Cristina da Rosa Fonseca da Silva: Possui graduação em Educação Artística pela Universidade do Estado de Santa Catarina - UDESC (1988), mestrado em Educação pela Universidade Federal de Santa Catarina - UFSC (1998) e doutorado em Engenharia de Produção pela UFSC (2004) na linha de mídia e conhecimento. É professora titular do Centro de Artes da UDESC. Atua como professora do Mestrado e doutorado em Artes Visuais da UDESC.

E-mail: cristinaudesc@gmail.com

Texto publicado em Currículo sem Fronteiras com autorização das autora 